\title{
Economic trends in European venture capital
}

\author{
Government initiatives, growth of small-cap markets, and a change in investor \\ attitudes has promoted an increase in European venture funding.
}

\author{
Patrick Van Beneden
}

\begin{abstract}
After years of playing the junior partner to the US biotechnology juggernaut, European biotech is growing up. According to Ernst \& Young's annual survey, Europe had more than 1,000 companies in 1997, an increase of $45 \%$ in one year. Most of these companies are private, located in clusters in the UK, Germany, France, the Benelux countries, and Sweden. Since 1994, employment by European biotechnology companies has increased $42 \%$, and R\&D spending is up $27 \%$, both topping US growth rates. Perhaps the most promising sign for European biotechs is the fact that
\end{abstract} pharmaceutical company executives are now searching aggressively for partnership opportunities on the eastern side of the Atlantic with the same vigor previously exhibited in North America. As a bonus, politicians across Europe-particularly in Germany-have jumped on the bandwagon, making clear that they want to make this sector a success.

A significant change within the European venture capital community has enabled this growth. European venture capitalists have always been a different breed from their risktaking North American counterparts. For much of the 1980s, providing seed capital and early-stage financing was a marginal part of the business on the European continent. Certainly, there was interesting research with commercial potential coming from European universities, but it was of little interest to venture capitalists, since much of this work was not protected by patent applications or licensed to the pharmaceutical industry. In addition, those of us in the venture capital game did not see many attractive, well-developed investment proposals for early-stage projects. And when we did, the entrepreneurs

Patrick Van Beneden is executive senior investment manager of GIMV, The Investment Company for Flanders, Karel Oomsstraat 37, 2018 Antwerp, Belgium (patrickvb@gimv.be).
Pharmaceutical company executives

are now searching aggressively for partnership opportunities on the eastern side of the Atlantic.

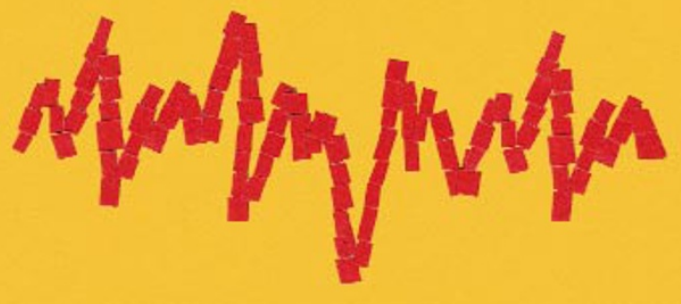

of the 1980s. We can now see many more promising research projects at universities. Academic institutions understand the importance of patent protection and are motivated to set up spinoffs to create value out of their technology. An increasing number of experienced managers and scientists are willing to leave their safe positions at pharmaceutical companies and universities to enter the high-risk, high-reward world of emerging European biotech.

In addition, the financial environment has changed greatly in Europe. There is more seed

were usually not prepared to leave their secure, well-paid jobs at large pharmaceutical companies to take the risks of founding or even working for a biotech company. It was not part of the European mindset then to participate, either with time or money, in high-risk ventures.

Venture capital-as defined on the European continent-was focused on management buyouts (MBOs) and on financing growth projects in low-technology industries. Funding startup biotechnology and high-technology companies was just not a priority. Pension funds and private investors tended to put their money in real estate, bonds, and loans to the government. Even if a venture capitalist had the inclination to invest in a biotech startup, there were no exit opportunities in the stock markets of Europe, and thus no easy way to redeem an initial investment in such a high-risk venture. Most of the traditional European stock exchanges required that a company demonstrate a strong financial track record in order to gain a listing on their exchanges. As a result, an initial public offering in Europe was more a paper exit opportunity than a reality. In contrast, US venture capitalists could construct a timeline from seed capital to a NASDAQ listing before investing a penny.

\section{A new world}

We have come a long way since the dark ages money and early-stage financing available today for high-tech startups, largely due to the continent-wide drop in interest rates that has made investments in bonds and government debt instruments less attractive. Real success stories, such as Genset (Paris), Innogenetics (Ghent, Belgium), PowderJect (Oxford, UK), and MorphoSys (Munich, Germany), proved to the financial community that you could make as much, if not more money with emerging high-tech companies as you could with MBOs or growth financing projects. As a result, there are now dedicated life science venture funds, such as the Medical Research Council Fund in the UK, and existing venture groups like Atlas, Abingworth, Apax, and TVM, with offices in several countries, have succeeded in generating larger pools of venture capital for investment in life science companies. There are even venture groups on the European continent that act on an international basis and collaborate in syndicates, in much the same that US venture capital firms operate.

According to figures from the European Venture Capital Association (Brussels), US venture capitalists still provide more money to their biotechnology startups, but the gap is getting smaller. While investments by US venture capitalists in biotechnology were flat in the US over the past several years, investments almost doubled in Europe. While 
much of this new activity has been centered in the UK, Germany has seen recent gains, with investments in biotechnology almost doubling between 1996 and 1997.

An important reason for the growth in biotechnology venture investing is that Europe now has financial markets accessible to smaller companies. London has gone the furthest with the London Stock Exchange and its small-cap cousin, the Alternative Investment Market. After a strong start, AIM celebrated its third birthday in June 1998 with over 300 new companies quoted on the market. Approximately $\$ 3.2$ billion has been raised on AIM, and approximately 50 have since moved to a full listing on the LSE. The success of this market has proven that small companies can both raise money and have an exit opportunity that can provide venture backers with a return on their investments.

Despite a miserable year for UK biotechnology sector-the BioCentury London Index fell $41 \%$ in 1998 - there were notable successes, too. PowderJect Pharmaceuticals was ranked as the UK's largest biotech company after it signed a deal with Glaxo Wellcome (London) and with Ares-Serono (Geneva). Product advances provided substantial gains for both Shire Pharmaceuticals (Andover, UK) and Celltech (Slough, UK). During the last 18 months, several companies have joined the public markets. On the LSE, new public companies included Quadrant Health Care (Nottingham, UK), Oxford Asymmetry (Oxford, UK), Oxford Glycosciences (Oxford, UK), and Bioglan Pharma (Hertfordshire, UK). Shire, which listed on the LSE in 1996, achieved another milestone for the European sector by successfully raising additional funds on NASDAQ.

The rise of EASDAQ has also been welcome news for biotechnology investment in Europe. EASDAQ has now approximately 40 companies listed and a total market cap of almost 17 billion euros. Already, there are five listed biotechnology companies: Innogenetics (Zwÿnaarde, Belgium), Chemunex (Maisons Alfort, France), Pharming (Leiden, The Netherlands), Orthovita (Malvern, PA), and Antisoma (London).

Both the Nouveau Marché and the Neuer Markt, the small-cap company exchanges of France and Germany, respectively, have gained considerable support over the past few years. It is fair to say that both French and German companies still have a preference for a listing on their native exchanges. In France, Genset, Cerep (Paris), and Transgène (Strasbourg) completed successful IPOs, with Transgène and Genset also quoted on NASDAQ. There have also been limited successes in going public on the Brussels, Copenhagen, and Stockholm exchanges.
Government initiatives, which are having an increasing influence on the European sector, will further sustain investments in biotechnology. The European Commission considers the biotech sector a priority, and as a result, European money will be made available for transnational research programs. In addition, individual member states are becoming more active. The German government, for example, has created one of the most biotech-friendly environments, setting up matching programs offered to companies that are backed by venture capital. Other countries have similar programs in place deploying research grants, guarantee schemes, tax incentives, outright loans, and early-stage financing.

Germany's efforts to become a world player in life sciences, and to close the leader-

\section{The European Commission considers the biotech sector a priority, and as a result, European money will be made available for trans- national research programs.}

ship gap between itself and the US and the UK, are also attracting foreign companies and investors. One of our portfolio companies, Ribozyme (Boulder, $\mathrm{CO}$ ), founded Atugen Biotechnology in Berlin, a \$50 million target validation company. Also, Sugen (S. San Francisco, CA) announced in November 1998 that it intends to establish a European affiliate in Switzerland and hopes to have its shares listed on the Neuer Markt by the end of this year.

\section{Remaining issues}

Though the funding environment in Europe has improved substantially over the past five years, there are still many obstacles to overcome. The number one problem may be one of human rather than capital resources-a lack of experienced managers to run startup biotechnology companies. Startups are all chasing the same limited pool of experienced managers who are ready and willing to leave large pharmaceutical companies. In this regard, the ongoing consolidation of the pharmaceutical industry might ease this bottleneck. European companies are also trying to lure European-born managers of US biotech companies back to Europe.

In addition, Europe may now be suffering from an embarrassment of riches, in which too much money is chasing after a limited, albeit growing number of interesting investment opportunities. This has produced some unrealistic valuations and deals that have been structured in a less-than-optimal manner. There are also storm clouds on the horizon as US and UK venture capitalists have pulled back from biotechnology. Many wonder if the private and public markets on the continent will follow a similar path.

We would also like to see the European secondary exchanges attract more IPOs as a way of reaching a critical mass and of attracting the attention of investors and analysts. As of the middle of 1998, NASDAQ still listed 135 European companies. One step that could help would be for the existing markets to harmonize. As they stand today, each secondary market still holds a national flavor. EASDAQ is intended to be the pan-European market for high-tech companies, but approximately $25 \%$ of all companies listed on EASDAQ are Belgian. And although Europe's secondary markets are technically linked through the Euro-NM agreement, no regulatory or legal harmonization has occurred. As a result, stocks on the Neuer Markt, NMAX, and Nouveau Marché are almost entirely national. This is even more stressed by the fact that institutional investors in France and Italy seem to receive fiscal incentives to invest in companies in local markets.

Another obstacle is that the bigger investment funds want to be in liquid names. As a result, all of Europe's secondary markets are driven by a few large names. On London's AIM, the top 10 companies represent $19 \%$ of that market's capitalization. On the Nouveau Marché, these companies account for 33\%, with figures of $38 \%$ on the Neuer Markt and $44 \%$ on EASDAQ. The industry would get better service if there were one unified stock market in place for growth companies and not several, smaller, nationally inspired stock markets.

\section{Conclusions}

Nevertheless, the overall outlook for the industry looks positive. Venture capitalists are now paying more attention to hightechnology and biotechnology projects, and investors on the continent seem to have a greater appetite for these new emerging companies. Entrepreneurs are coming forward with better business plans and governments are creating an environment that encourages and supports young biotech companies with infrastructure and funding. We expect to see more partnering activity, not only between biotechnology and pharmaceutical companies, but also between biotechnology companies, which will not only raise funds but also awareness among investors. 